\title{
Serum albumin is a strong predictor of survival in patients with advanced-stage non-small cell lung cancer treated with erlotinib
}

\author{
O. FIALA ${ }^{1,2, *}$, M. PESEK ${ }^{3}$, J. FINEK ${ }^{1}$, J. RACEK ${ }^{4}$, M. MINARIK ${ }^{5,6}$, L. BENESOVA ${ }^{5}$, Z. BORTLICEK ${ }^{7}$, O. SOREJS ${ }^{1}$, R. KUCERA ${ }^{8}$, O. TOPOLCAN ${ }^{8}$
}

${ }^{1}$ Department of Oncology and Radiotherapy, Medical School and Teaching Hospital in Pilsen, Charles University in Prague, Czech Republic; ${ }^{2}$ Biomedical Center, Faculty of Medicine in Pilsen, Charles University in Prague, Czech Republic; ${ }^{3}$ Department of Pneumology, Medical School and Teaching Hospital in Pilsen, Charles University in Prague, Czech Republic; ${ }^{4}$ Istitute of Clinical Biochemistry and Hematology Medical School and Teaching Hospital in Pilsen, Charles University in Prague, Czech Republic; ${ }^{5}$ Center for Applied Genomics of Solid Tumors, Genomac Research Institute, Prague, Czech Republic; ${ }^{6}$ Department of Analytical Chemistry, Faculty of Sciences, Charles University in Prague, Czech Republic; ${ }^{7}$ Institute of Biostatistics and Analysis, Faculty of Medicine, Masaryk University, Brno, Czech Republic; ${ }^{8}$ Department of Nuclear Medicine, Medical School and Teaching Hospital in Pilsen, Charles University in Prague, Czech Republic

${ }^{*}$ Correspondence: fiala.o@centrum.cz

Received October 1, 2015 / Accepted December 15, 2015

\begin{abstract}
Molecular targeted therapy based on tyrosine kinase inhibitors (TKI), directed at epidermal growth factor receptor (EGFR) is one of the novel effective agents in management of advanced-stage of Non Small Cell Lung cancer (NSCLC). However several candidate predictors have been extensively studied, apart from activating EGFR gene mutations, no reliable biochemical or molecular predictors of response to erlotinib have been validated. The aim of our retrospective study was to evaluate the association of baseline serum albumin with outcomes in a large cohort of patients with advanced-stage NSCLC treated with erlotinib. Clinical data of 457 patients with locally-advanced (III B) or metastatic stage (IV) NSCLC treated with erlotinib were analysed. Serum samples were collected and the measurement was performed one day before the initiation of erlotinib treatment. Before the treatment initiation, low albumin was $(<35 \mathrm{~g} / \mathrm{l})$ measured in $37(8.1 \%)$ patients and normal albumin $(\geq$ $35 \mathrm{~g} / \mathrm{l})$ was measured in 420 (91.9\%). The median PFS and OS for patients with low serum albumin was 0.9 and 1.9 months compared to 1.9 and 11.4 months for patients with normal serum albumin $(p=0.001$ and $p<0.001)$. The multivariate Cox proportional hazards model revealed that $E G F R$ mutation status $(\mathrm{HR}=2.50 ; \mathrm{CI}: 1.59-3.92 ; p<0.001)$ and pretreatment serum albumin ( $\mathrm{HR}=1.73$; CI: 1.21-2.47; $p=0.003$ ) were significant independent predictive factors for PFS, whereas EGFR mutation status ( $\mathrm{HR}=3.14$; CI: $1.70-5.81 ; p<0.001)$, stage (HR=1.48; CI: 1.09-2.02; $p=0.013)$, ECOG PS (HR=1.77; CI: 1.37-2.29; $p<0.001)$ and pretreatment serum albumin $(\mathrm{HR}=4.60$; $\mathrm{CI}: 2.98-7.10 ; p<0.001)$ were significant independent predictive factors for OS. In conclusion, the results of present retrospective study indicate that pretreatment hypoalbuminemia is associated with poor outcome of NSCLC patients treated with erlotinib. Based on these results, measuement of serum albumin is an objective laboratory method feasible for estimation of prognosis of patients with advanced-stage NSCLC.
\end{abstract}

Key words: albumin, lung cancer, NSCLC, EGFR-TKI, erlotinib, prediction, biomarker

Lung cancer is the principal cause of cancer-related mortality in developed countries [1, 2]. Non-small cell lung cancer (NSCLC) is the most common histological type constituting more than $80 \%$ of all lung carcinomas [3]. Molecular targeted therapy based on tyrosine kinase inhibitors (TKI), directed at epidermal growth factor receptor (EGFR) is one of the novel effective agents in management of advanced-stage NSCLC. Erlotinib is a reversible EGFR-TKI that inhibits the EGFR tyrosine kinase by competing with adenosine triphosphate (ATP) at the ATP-binding site and prevents its phosphoryla- tion and downstream signaling. However several candidate predictors have been extensively studied, apart from activating EGFR gene mutations, no reliable biochemical or molecular predictors of response to erlotinib have been validated. Patients with advanced NSCLC frequently present with malnutrition and subsequently, with hypoalbuminemia $[4,5]$. Accumulating data has highlighted a correlation between hypoalbuminemia and survival in cancer patients. Hypoalbuminemia has been reported as a negative prognostic factor for survival in patients with colorectal carcinoma $[6,7]$, gastric carcinoma [8], breast 
cancer [9] and NSCLC [10]. The aim of our retrospective study was to evaluate the association of baseline serum albumin with outcomes in a large cohort of patients with advanced-stage NSCLC treated with erlotinib.

\section{Patients and methods}

Patients and treatment. We retrospectively analysed clinical data of 457 patients with cytologically or histologically confirmed locally-advanced (IIIB) or metastatic stage (IV) NSCLC treated with erlotinib. Patients were treated between years 2005 and 2014. Erlotinib was administered orally at the standard approved dose of $150 \mathrm{mg}$ daily. The treatment was continued until disease progression or development of intolerable toxic effects. Dose interruption or reduction was permitted in the event of treatment-related toxicity.

Data source. The clinical registry TULUNG (http://tulung. registry.cz/), in which Faculty Hospital Pilsen is participating since its creation, is a non-interventional post-registration database of epidemiological and clinical data of patients with advanced-stage NSCLC treated with targeted therapies in the Czech Republic. The registry contains anonymised individual patient data including demographic parameters, initial staging and disease characteristics, baseline patient information at the start of targeted therapy, as well as data on survival and adverse events which is updated at least twice a year. Data on pretreatment serum levels of albumin were extracted from the hospital information system and merged to the registry data. The protocol was approved by the independent ethics committee of the University Hospital Pilsen and complied with the International Ethical Guidelines for Biomedical Research Involving Human Subjects, Good Clinical Practice guidelines, the Declaration of Helsinki, and local laws.

Clinical monitoring. The treatment was prospectively monitored and the clinical course of patients was continuously assessed at specific time points. Clinical follow-up controls including physical examination, plain chest $\mathrm{X}$-ray and routine laboratory tests was performed every 3-4 weeks; computed tomography (CT) or positron emission tomography - (PET)CT was performed after two or three months of the treatment. The objective tumor response was assessed by investigators using Response Evaluation Criteria in Solid Tumors (RECIST) [11].

Albumin measurement. Serum samples were collected and the measurement was performed one day before the initiation of erlotinib treatment. Serum albumin was measured with bromcresol green, supplied by Beckman Coulter (Brea, CA, USA) on an AU 2700 or AU 5800 (since 2014) analyzers from Beckman Coulter. The measurement was performed in the central biochemical laboratory at the Department of Clinical Biochemistry and Hematology, Medical School and Teaching Hospital in Pilsen, using the cut-off value of $35 \mathrm{~g} / \mathrm{l}$, which is the normal value measured by the used test.

EGFR mutation analysis. The tumor specimens acquired during initial bronschoscopy examination were evaluated by a senior cytologist using standard giemsa staining. In a few cases, a tumor biopsy was processed into formalin-fixed paraffin embedded (FFPE) histological sections. The cytology slides or, eventually, the FFPE sections, were submitted for molecular genetic testing, which included detection of somatic mutations in exon 19 (deletion) and 21 (L858R) of EGFR gene. If necessary, tumor cells were carefully selected and removed from the samples by laser microdissection using a P.A.L.M. microlaser instrument (Carl Zeiss MicroImaging $\mathrm{GmbH}$, Jena, Germany). The microdissected cells were collected directly into the polymerase chain reaction (PCR) buffer and processed without a special DNA extraction step. In all other cases, the DNA was extracted from tissue cells by a standard spin column procedure using JetQuick Tissue DNA Issolation Kit (Genomed GmbH, Loehne, Germany). Mutations were tested by Genoscan mutation detection kits (Genomac International, Prague, Czech Republic) utilizing a denaturing capillary electrophoresis (DCE) technique on an ABI PRISM 3100 16-capillary genetic analyzer (Applied Biosystems, Foster City, CA, USA). Detected mutations were confirmed by Sanger DNA sequencing using a BigDye v 3.0 chemistry (Applied Biosystems, Foster City, CA, USA). In rare cases, where the overall fraction of mutated DNA was below the $20 \%$ threshold for DNA sequencing, mutation was identified indirectly after forming only a homoduplex fragment with a given known mutation reference standard.

Statistics. Standard frequency tables and descriptive statistics were used to characterize sample data set. MannWhitney test was used for comparison of albumin between different subgroups of patients. . PFS and OS were estimated using Kaplan Meier method and all point estimates were accompanied by $95 \%$ confidence intervals. Progression-free survival (PFS) was defined from the date of erlotinib initiation until the date of first documented progression or death. Overall survival (OS) was defined from the date of erlotinib initiation until the date of death due to any cause. Patients who had not progressed or died were censored at the date of last follow-up. Statistical significance of the differences in Kaplan-Meier estimates was assessed using the log-rank test. Multivariable Cox proportional hazards model was used to evaluate the effect of all potential prognostic factors on the survival measures. Statistical significance of hazard ratios were assessed by means of Wald test. As a level of statistical significance $\alpha=0.05$ was used.

\section{Results}

Patient characteristics. The cohort included 283 (61.9\%) men and 174 (38.1\%) women; $239(52.3 \%)$ current-smokers, 141 (30.9\%) former-smokers and 77 (16.8\%) never-smokers; $242(53.0 \%)$ patients with non-squamous histology and 215 (47.0\%) patients with other histological type; $359(78.6 \%)$ patients with stage IV and $98(21.4 \%)$ patients with stage IIIB; 290 (63.5\%) patients with ECOG PS 0 or 1 and 167 (36.5) patients with ECOG PS 2 or 3; 47 (10.3\%) patients treated 
A

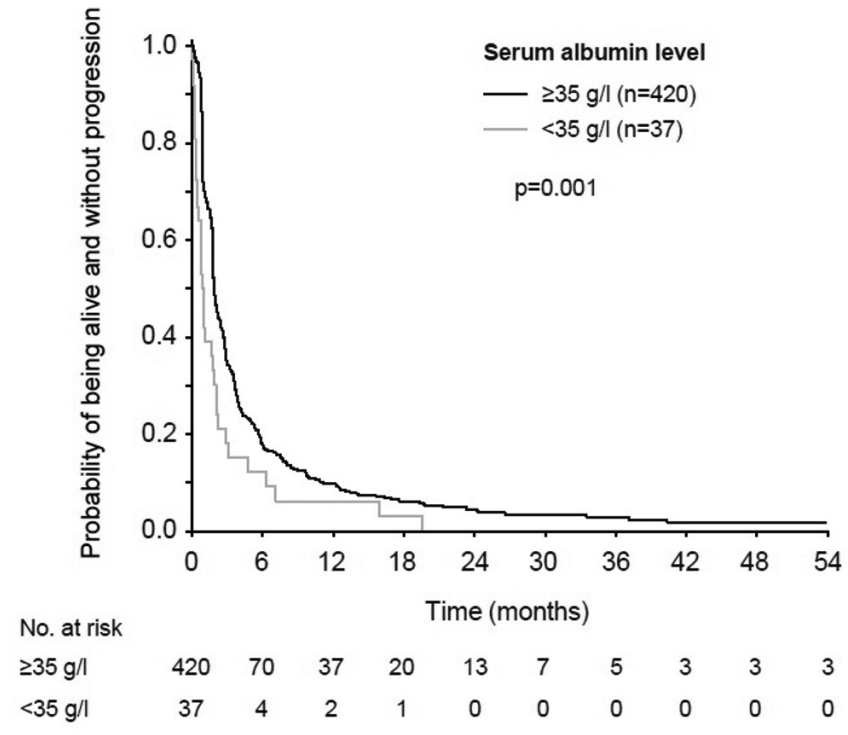

B

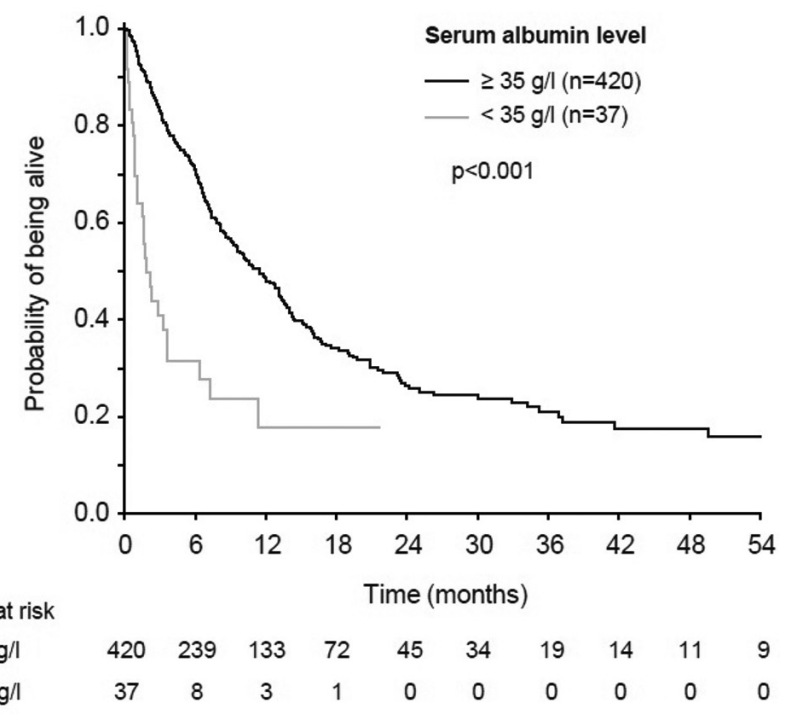

Figure 1. Progression-free (A) and overall (B) survival from erlotinib treatment initiation according to serum albumin level

in the first line and $229(89.7 \%)$ patients treated in higher lines; 31 (6.8\%) patients harbouring EGFR mutation, 215 (47.0\%) patients harbouring wild-type EGFR gene and 211 (46.2\%) patients with unknown EGFR status. The baseline patient characteristics are summarized in Table 1 . The median follow-up of the cohort was 6.5 months, the median OS was 10.4 months (95\% CI: 8.3-12.5), and the median PFS was 1.9 months (95\% CI: 1.8-2.1).

Baseline serum albumin levels. Before the treatment initiation, low albumin was $(<35 \mathrm{~g} / \mathrm{l})$ measured in $37(8.1 \%)$ patients and normal albumin $(\geq 35 \mathrm{~g} / \mathrm{l})$ was measured in 420 (91.9\%). Low baseline albumin levels were significantly associated with worse ECOG PS $(p<0.001)$ and treatment in higher line $(p=0.001)$.

Relation between baseline serum albumin and survival. The median PFS and OS for patients with low serum albumin was 0.9 and 1.9 months compared to 1.9 and 11.4 months for patients with normal serum albumin $(p=0.001$ and $p<0.001)$. The PFS and OS data are summarized in Table 2 and survival curves are shown in Figure 1. Baseline clinical parameters were assessed together with serum albumin levels multivariate model. The multivariate Cox proportional hazards model revealed that pretreatment serum albumin $(\mathrm{HR}=1.66$; CI: 1.16-2.38; $p=0.005), E G F R$ mutation status $(\mathrm{HR}=2.43$; CI: $1.55-3.82 ; p<0.001)$ and stage $(\mathrm{HR}=1.29$; CI: $1.01-1.64$; $p=0.038$ )were significant independent predictive factors for $\mathrm{PFS}$, whereas pretreatment serum albumin $(\mathrm{HR}=4.72$; CI: 3.07-7.24; $p<0.001)$, EGFR mutation status ( $\mathrm{HR}=2.48$; CI: 1.32 4.63; $p=0.005)$, stage $(\mathrm{HR}=1.49$; CI: $1.09-2.03 ; p=0.012)$ and ECOG PS (HR=1.81; CI: $1.39-2.35 ; p<0.001)$ were significant independent predictive factors for OS (Table 3 ).
Table 1. Baseline characteristics of patients

\begin{tabular}{llc}
\hline Characteristic & Category & $\mathbf{n}(\%)$ \\
\hline Sex & Female & $174(38.1)$ \\
Age & Male & $283(61.9)$ \\
Smoking & $<70$ years & $343(75.1)$ \\
& $\geq 70$ years & $114(24.9)$ \\
& Current-smoker & $239(52.3)$ \\
Histology & Former-smoker & $141(30.9)$ \\
& Never-smoker & $77(16.8)$ \\
& Non-squamous & $242(53.0)$ \\
& Adenocarcinoma & $213(46.6)$ \\
& NOS & $28(6.1)$ \\
& Large cell carcinoma & $1(0.2)$ \\
Other & $215(47.0)$ \\
Squamous & $211(46.2)$ \\
Stage & Adenosquamous & $1(0.2)$ \\
ECOG PS & Other & $3(0.7)$ \\
& IIIB & $98(21.4)$ \\
EGFR mutation status & EGFR mutation & $359(78.6)$ \\
& Wild-type & $10(2.2)$ \\
& PS 0 & $280(61.3)$ \\
& PS 1 & $149(32.6)$ \\
& PS 2 & $18(3.9)$ \\
& PS 3 & $47(10.3)$ \\
& 1st line & $229(50.1)$ \\
2nd line & $175(38.3)$ \\
& 3rd line & $6(1.3)$ \\
& 4 th or higher line & $215(47.8)$ \\
& & $211(46.2)$ \\
\hline & & \\
& &
\end{tabular}


Table 2. Progression-free and overall survival from erlotinib treatment initiation according to serum albumin level

\begin{tabular}{|c|c|c|c|}
\hline \multicolumn{4}{|c|}{ Serum albumin level } \\
\hline & $<35 \mathrm{~g} / \mathbf{l}(\mathrm{n}=37)$ & $\geq 35 \mathrm{~g} / \mathbf{l}(\mathrm{n}=420)$ & \\
\hline Median PFS (95\% CI) & 0.9 months $(0.6-1.2)$ & 1.9 months $(1.8-2.1)$ & 0.001 \\
\hline 3-months PFS (95\% CI) & $17.9 \%(5.1-30.8)$ & $35.0 \%(30.4-39.6)$ & \\
\hline 6-months PFS (95\% CI) & $12.0 \%(1.0-22.9)$ & $18.0 \%(14.2-21.8)$ & \\
\hline Median OS (95\% CI) & 1.9 months $(0.9-2.9)$ & 11.4 months (9.6-13.3) & $<0.001$ \\
\hline 6-months OS (95\% CI) & $31.5 \%(15.9-47.1)$ & $70.8 \%(66.2-75.4)$ & \\
\hline 12-months OS $(95 \% \mathrm{CI})$ & $17.7 \%(2.6-32.8)$ & $48.2 \%(42.9-53.6)$ & \\
\hline
\end{tabular}

Table 3. Multivariable Cox-proportional hazards model for progression-free and overall survival

\begin{tabular}{|c|c|c|c|c|c|}
\hline \multirow{2}{*}{ Parameter } & \multirow{2}{*}{ Category } & \multicolumn{2}{|c|}{ Progression-free survival } & \multicolumn{2}{|c|}{ Overall survival } \\
\hline & & HR (95\% CI) & $p$-value & HR (95\% CI) & $p$-value \\
\hline \multirow{2}{*}{ Serum albumin level } & $\geq 35 \mathrm{~g} / 1$ & 1.00 & - & 1.00 & - \\
\hline & $<35 \mathrm{~g} / 1$ & $1.66(1.16-2.38)$ & 0.005 & $4.72(3.07-7.24)$ & $<0.001$ \\
\hline \multirow[t]{2}{*}{ Sex } & Female & 1.00 & - & 1.00 & - \\
\hline & Male & $1.08(0.87-1.33)$ & 0.476 & $1.15(0.88-1.49)$ & 0.309 \\
\hline \multirow[t]{2}{*}{ Age } & $<70$ years & 1.00 & - & 1.00 & - \\
\hline & $\geq 70$ years & $0.91(0.73-1.15)$ & 0.427 & $0.97(0.73-1.29)$ & 0.841 \\
\hline \multirow[t]{2}{*}{ Smoking } & Never-smoker & 1.00 & - & 1.00 & - \\
\hline & Current-smoker \& Former-smoker & $1.16(0.86-1.56)$ & 0.332 & $0.99(0.68-1.46)$ & 0.967 \\
\hline \multirow[t]{2}{*}{ EGFR mutation status } & EGFR mutation & 1.00 & - & 1.00 & - \\
\hline & Wild-type \& unknown & $2.43(1.55-3.82)$ & $<0.001$ & $2.48(1.32-4.63)$ & 0.005 \\
\hline \multirow[t]{2}{*}{ Stage } & IIIB & 1.00 & - & 1.00 & - \\
\hline & IV & $1.29(1.01-1.64)$ & 0.038 & $1.49(1.09-2.03)$ & 0.012 \\
\hline \multirow[t]{2}{*}{ ECOG PS } & PS $0 \&$ PS 1 & 1.00 & - & 1.00 & - \\
\hline & PS 2 \& PS 3 & $1.21(0.98-1.49)$ & 0.083 & $1.81(1.39-2.35)$ & $<0.001$ \\
\hline \multirow{2}{*}{ Line of therapy } & 1st line & 1.00 & - & 1.00 & - \\
\hline & 2nd and higher & $0.81(0.57-1.14)$ & 0.231 & $0.98(0.63-1.54)$ & 0.940 \\
\hline
\end{tabular}

\section{Discussion}

Albumin is the most abundant protein in human blood plasma and constitutes approximately half of the blood serum protein. It is produced by the liver cells and maintains intravascular oncotic pressure, transports hormones, fatty acids and other compounds and buffers blood $\mathrm{pH}$ among other functions. Malnutrition and systemic inflamatory response (SIR) suppress albumin synthesis [12]. The normal serum albumin level in adults ranges between 35 and $50 \mathrm{~g} / \mathrm{l}$. Serum albumin concentration has been regularly used as a biochemical marker of long-term nutritional status; it is one of the easiest parameters to measure and that which best reflects the state of visceral protein [13]. Decrease of albumin serum levels reflects both the loss of the amount of lean tissue and SIR [14-17]. Malnutrition commonly occurs in cancer patients. Patients with advanced NSCLC have an important energy expenditure caused by increased tumor metabolism [18]. Those patients frequently present with malnourishment and subsequently, with hypoalbuminemia $[4,5,19,20]$ caused by tumor activ- ity via increased fractional catabolic rate (FCR) and also by decreased albumin synthesis. Notably, the majority of patients suffer from loss of appetite [21] resulting in diminished food intake [22].

Randomised phase III clinical trials demonstrated efficacy and safety of erlotinib in the treatment of patients with advanced-stage NSCLC [23-26]. Increasing evidence suggests that proper patient selection through the identification and use of predictive biomarkers may maximize the efficacy of targeted anticancer therapies. It has been well-established that activating EGFR gene mutations encoding the tyrosine kinase domain (predominantly the exon 19 deletions or the point mutations in exon 21 termed L858R) predict favourable response to the treatment with EGFR-TKIs in patients with advanced-stage NSCLC [27-30]. On the other hand, the efficacy of EGFR-TKIs in the predominant group of NSCLC patients harbouring wild-type EGFR gene, is low and there is no available predictive biomarker. Several studies have shown that malnutrition has been associated with worse performance status, reduced quality of life (QoL), increased hospitaliza- 
tion, increased susceptibility to infection and also increased chemotherapy-induced toxicity [31-34]. Based on the data from previous studies, mostly performed on patients treated with chemotherapy, we conducted the present study focussed on the prognostic role of pretreatment serum albumin in a large cohort of patients with advanced-stage NSCLC treated with erlotinib. We observed significantly shorter PFS and OS for patients with hypalbuminemia compared to those with normal serum albumin ( 0.9 and 1.9 months compared to 1.9 and 11.4 months, $p=0.001$ and $p<0.001$ ), and the multivariate Cox proportional hazards model confirmed that hypalbuminemia was independently associated with shorter survival (PFS: $\mathrm{HR}=1.73 ; p=0.005$ and OS: $\mathrm{HR}=4.72 ; p<0.001$ ). Short PFS for patients with hypoalbuminemia suggests low efficacy of erlotinib in this high-risk group. However, it cannot be concluded with certainty that those patients will not benefit from erlotinib, because the present study did not include control group treated with placebo. Our results showing a remarkable short OS for patients with hypoalbuminemia suggest that pretreatment serum albumin is a strong predictor of survival determining patients in high risk of early death. These results are in agreement with those reported by Park et al. who observed similarly remarkable difference in OS according to pretreatment serum albumin ( 2.8 vs. 9.8 months; $p<0.001)$ [35]. Notably, the multivariate Cox proportional hazards model showed that hypoalbuminemia was the strongest factor predicting OS, even stronger than EGFR mutation, stage or ECOG PS. Moreover, basic nutritional screening using serum albumin measurement might allow identification of high-risk patients and the implementation of an intensive nutritional support might be beneficial.

The principal limitations of the present study are the retrospective nature and relatively limited number of patients with hypoalbuminemia.

In conclusion, the results of the present retrospective study indicate that pretreatment hypoalbuminemia is associated with poor outcome of NSCLC patients treated with erlotinib. Based on the present study results, measuement of serum albumin is an objective laboratory method feasible for estimation of prognosis of patients with advanced-stage NSCLC.

Acknowledgements: The authors would like to thank all patients voluntarily taking part in the observational, population-based registry TULUNG. This study was supported by the National Sustainability Program I (NPU I) Nr. LO1503 provided by the Ministry of Education Youth and Sports of the Czech Republic.

\section{References}

[1] JEMAL A, BRAY F, CENTER MM, FERLAY J, WARD E et al. Global cancer statistics. CA Cancer J Clin 2011; 61: 69-90. http://dx.doi.org/10.3322/caac.20107

[2] FERLAY J, PARKIN DM, STELIAROVA-FOUCHER E. Estimates of cancer incidence and mortality in Europe in 2008.
Eur J Cancer 2010; 46: 765-781. http://dx.doi.org/10.1016/j. ejca.2009.12.014

[3] BRAMBILLA E., TRAVIS WD, COLBY TV, CORRIN B, SHIMOSATO Y. The new World Health Organization classification of lung tumors. Eur Respir J 2001; 18: 1059-1068. http://dx.doi.org/10.1183/09031936.01.00275301

[4] SARHILL N, MAHMOUD F, WALSH D, NELSON KA, KOMURCU $S$ et al. Evaluation of nutritional status in advanced metastatic cancer. Support Care Cancer 2003; 1 : 652-659. http://dx.doi.org/10.1007/s00520-003-0486-0

[5] McMILLAN DC. An inflammation-based prognostic score and its role in the nutrition-based management of patients with cancer. Proc Nutr Soc 2008; 67: 257-262. http://dx.doi. org/10.1017/S0029665108007131

[6] CENGIZ O, KOCER B, SUMELI S, SANTICKY MJ, SORAN A. Are pretreatment serum albumin and cholesterol levels prognostic tools in patients with colorectal carcinoma? Med Sci Monitor 2006; 12: 240-247.

[7] BOONPIPATTANAPONG T, CHEWATANAKORNKUL $S$. Preoperative carcinoembryonic antigen and albumin in predicting survival in patients with colon and rectal carcinomas. J Clin Gastroenterol 2006; 40: 592-595. http://dx.doi. org/10.1097/00004836-200608000-00006

[8] ONATE-OCANA LF, AIELLO-CROCIFOGLIO V, GALLARDO-RINCON D, HERRERA-GOEPFERT R, BROM-VALLADARES R et al. Serum albumin as a significant prognostic factor for patients with gastric carcinoma. Ann Surg Oncol 2007; 14: 381-389. http://dx.doi.org/10.1245/s10434006-9093-x

[9] LIS CG, GRUTSCH JF, VASHI PG, LAMMERSFELD CA. Is serum albumin an independent predictor of survival in patients with breast cancer? Jpen-Parenter Enter 2003; 27: 10-15. http://dx.doi.org/10.1177/014860710302700110

[10] ESPINOSA E, FELIU J, ZAMORA P, BARON MG, SANCHEZ $J J$ et al. Serum-Albumin and Other Prognostic Factors Related to Response and Survival in Patients with Advanced Nonsmall Cell Lung-Cancer. Lung Cancer. 1995; 12: 67-76. http://dx.doi. org/10.1016/0169-5002(95)00407-R

[11] THERASSE P, ARBUCK SG, EISENHAUER EA, WANDERS J, KAPLAN RS et al. New guidelines to evaluate the response to treatment in solid tumors. European Organization for Research and Treatment of Cancer, National Cancer Institute of the United States, National Cancer Institute of Canada. J Natl Cancer Inst 2000; 3: 205-216. http://dx.doi.org/10.1093/ jnci/92.3.205

[12] YEUN JY, KAYSEN GA. Factors influencing serum albumin in dialysis patients. Am J Kidney Dis 1998; 32(6 Suppl 4): S118125. http://dx.doi.org/10.1016/S0272-6386(98)70174-X

[13] D'ANGIO RG. Is there a role for albumin administration in nutrition support? The Annals of pharmacotherapy 1994; 28: 478-482.

[14] McMILLAN DC. Systemic inflammation, nutritional status and survival in patients with cancer. Curr Opin Clin Nutr Metab Care 2009; 12: 223-226. http://dx.doi.org/10.1097/ MCO.0b013e32832a7902

[15] DETSKY AS, BAKER JP, MENDELSON RA, WOLMAN SL, WESSON DE et al. Evaluating the accuracy of nutritional 
assessment techniques applied to hospitalized patients: methodology and comparisons. Jpen 1984; 8: 153-159. http:// dx.doi.org/10.1177/0148607184008002153

[16] KUZUYA M, KANDA S, KOIKE T, SUZUKI Y, SATAKE S et al. Evaluation of Mini-Nutritional Assessment for Japanese frail elderly. Nutrition 2005; 21: 498-503. http://dx.doi. org/10.1016/j.nut.2004.08.023

[17] LAKY B, JANDA M, BAUER J, VAVRA C, CLEGHORN G et al. Malnutrition among gynaecological cancer patients. European journal of clinical nutrition 2007; 61: 642-646.

[18] HOLROYDE CP, REICHARD GA Jr. General metabolic abnormalities in cancer patients: anorexia and cachexia. The Surgical clinics of North America 1986; 66: 947-956.

[19] BUSCH E, VERAZIN G, ANTKOWIAK JG, DRICOLL D, TAKITA H Pulmonary complications in patients undergoing thoracotomy for lung carcinoma. Chest 1994; 105: 760-766. http://dx.doi.org/10.1378/chest.105.3.760

[20] BASHIR Y, GRAHAM TR, TORRANCE A, GIBSON GJ, CORRIS PA. Nutritional state of patients with lung cancer undergoing thoracotomy. Thorax 1990; 45: 183-186. http:// dx.doi.org/10.1136/thx.45.3.183

[21] DY SM. Enteral and Parenteral Nutrition in Terminally Ill Cancer Patients: A Review of the Literature. Am J Hosp Palliat Care 2006; 23: 369-377. http://dx.doi. org/10.1177/1049909106292167

[22] CASADO-COBO SCR. Dietary interventions in Cancer. Rev Oncol 2004; 6: 496-500.

[23] SHEPHERD FA, RODRIGUES PEREIRA J, CIULEANU T, TAN EH, HIRSH V et al. Erlotinib in previously treated non-small-cell lung cancer. N Engl J Med 2005; 353: 123-132. http://dx.doi.org/10.1056/NEJMoa050753

[24] CIULEANU T, STELMAKH L, CICENAS S, MILIAUSKAS S, GRIGORESCU AC et al. Efficacy and safety of erlotinib versus chemotherapy in second-line treatment of patients with advanced, non-small-cell lung cancer with poor prognosis (TITAN): a randomised multicentre, open-label, phase 3 study. Lancet Oncol 2012; 13: 300-308. http://dx.doi.org/10.1016/ S1470-2045(11)70385-0

[25] ZHOU C, WU YL, CHEN G, FENG J, LIU XQ et al. Erlotinib versus chemotherapy as first-line treatment for patients with advanced EGFR mutation-positive non-small-cell lung cancer (OPTIMAL, CTONG-0802): a multicentre, open-label, randomised, phase 3 study. Lancet Oncol 2011; 12: 735-742. http://dx.doi.org/10.1016/S1470-2045(11)70184-X

[26] ROSELL R, CARCERENY E, GERVAIS R, VERGNENGRE A, MASSUTI B et al. Erlotinib versus standard chemotherapy as first-line treatment for European patients with advanced
EGFR mutation-positive non-small-cell lung cancer (EURTAC): a multicentre, open-label, randomised phase 3 trial. Lancet Oncol 2012; 13: 239-246. http://dx.doi.org/10.1016/ $\underline{\text { S1470-2045(11)70393-X }}$

[27] LYNCH TJ, BELL DW, SORDELLA R, GURUBHAGAVATULA S, OKIMOTO RA et al. Activating mutations in the epidermal growth factor receptor underlying responsiveness of non-small-cell lung cancer to gefitinib. N Engl J Med 2004; 350: 2129-2139. http://dx.doi.org/10.1056/ NEJMoa040938

[28] PAEZ JG, JANNE PA, LEE JC, TRACY S, GREULICH H et al. EGFR mutations in lung cancer: Correlation with clinical response to gefitinib therapy. Science 2004; 304: 1497-1500. http://dx.doi.org/10.1126/science.1099314

[29] ZHU CQ, da CUNHA SANTOS G, DING K, SAKURADA A, CUTZ JC et al. Role of KRAS and EGFR as biomarkers of response to erlotinib in National Cancer Institute of Canada Clinical Trials Group Study BR.21. J Clin Oncol 2008; 26: 4268-4275. http://dx.doi.org/10.1200/JCO.2007.14.8924

[30] HIRSCH FR, VARELLA-GARCIA M, BUNN PA Jr, FRANKLIN WA, DZIADZIUSZKO R et al. Molecular predictors of outcome with gefitinib in a phase III placebo-controlled study in advanced non-small cell lung cancer. J Clin Oncol 2006; 24: 5034-5042. http://dx.doi.org/10.1200/JCO.2006.06.3958

[31] SUNG JBG, JOSHI M, BOCHICCHIO K, COSTAS A, TRACY $\mathrm{K}$ et al. Admission serum albumin is predicitve of outcome in critically ill trauma patients. Am Surg 2004; 70: 1099-1102.

[32] KUZUYA MIS, ENOKI H, OKADA K, IGUCHI A Is serum albumin a good marker for malnutrition in the physically impaired elderly? Clin Nutr 2007; 26: 84-90. http://dx.doi. org/10.1016/j.clnu.2006.07.009

[33] WIN TRA, WELLS F, LAROCHE C The incidence and impact of low body mass index on patients with operable lung cancer. Clin Nutr 2007; 26: 440-443. http://dx.doi.org/10.1016/j. clnu.2007.01.009

[34] ARRIETA O, MICHEL ORTEGA RM, VILLANUEVARODRIGUEZ G, SERNA-THOME MG, FLORES-ESTRADA

$\mathrm{D}$ et al. Association of nutritional status and serum albumin levels with development of toxicity in patients with advanced non-small cell lung cancer treated with paclitaxel-cisplatin chemotherapy: a prospective study. BMC Cancer 2010; 10: 50. http://dx.doi.org/10.1186/1471-2407-10-50

[35] PARK MJ, LEE J, HONG JY, CHOI MK, YI JH et al. Prognostic Model to Predict Outcomes in Nonsmall Cell Lung Cancer Patients Treated With Gefitinib as a Salvage Treatment. Cancer 2009; 115: 1518-1530. http://dx.doi.org/10.1002/cncr.24151 